\title{
The Case For Case Studies: Deriving Theory From Evidence
}

\author{
Robert Klonoski, JD, D.Mgt., Mary Baldwin College, USA
}

\begin{abstract}
While case studies appear frequently in business classrooms as learning exercises, they appear only infrequently in scholarly journals as an accepted basis on which to demonstrate a theory or test a hypothesis. While scholars have contributed much in recent years to improving the rigor and design of business case studies, this research approach may yet be underutilized. The academic approach to the study of law in the US and England draws heavily on the use of case studies; management scholars may benefit from an understanding of the ways in which lawyers construct, analyze, and draw lessons from cases.
\end{abstract}

Keywords: Business Case Study; Case Study Method; Socratic Method

\section{INTRODUCTION}

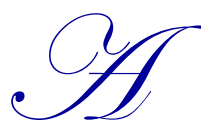

dramatic change in the pedagogy used by law schools was introduced into Harvard in 1870 by Christopher Columbus Langdell (Kimball, 2009). In teaching a class in Contracts, Langdell departed from the traditional lecture-and-notes system common to law and business schools and used cases pled before the courts as the basis for discussion. He introduced the "Socratic method" to the modern classroom and led discussions in which students were expected to analyze the cases presented and to derive the rationale for their decisions and the rules that were to follow. This pedagogical style began its spread to other law schools by 1890; it became the dominant method used in law schools in the US by 1920 and remains as such through the current day (Jackson, 2011:142).

By 1920, Harvard Business School had adopted the case study as its primary pedagogical approach. Case studies in business, just as in law, had at first been integrated into curriculums as demonstrations of theoretical points - examples of how a theory could be applied in actual practice (Baldwin, 1900:261). With time, cases began to be approached as analytical exercises - methods for discovering the "how" and "why" of contemporary events (Yin, 2009:8). In more recent years, the Harvard Business School has incorporated "immersion" experiences into its curriculum, making case studies live and interactive (HBS, n.d.). A key benefit of placing students in working environments is that they are able to observe nuances of systems and behaviors that may not be available in a written case, and to track the consequences of environmental changes - a practice founded in the Kolb Learning Cycle theory (Kolb, 1984:21). This being said, not all colleges and universities have the capability to provide an extended set of immersion experiences for the students in their programs, and so the written case study remains as a mainstay of business school education.

These two disparate approaches were established nearly a century ago but remain largely in place in collegiate systems in the US today. Business case study research has been used as the basis for developing an understanding of a specific phenomenon or for "exposing ... causal processes" - the relationships between factors causing events to occur (Wynn and Williams, 2012:804). Generalizing lessons learned from case study research remains a challenge. The first - and obvious - concern is whether a study based on a single or a limited set of events can be used to predict behavior in diverse circumstances (Bygstad, 2010:167). Beyond this, business case studies are generally constructed to explain the mechanisms contributing to a described event and to interpret its social, cultural, and organizational meanings rather than to create rules for or predictions about future events (Wynn and Williams, 2012:793). 
In the study of law, events are generally used to construct principles; in the study of management, principles are generally used to interpret events. In this study we ask: What are the differences in the manner in which legal and business studies approach case studies? And, as a corollary, can and under what criteria can management studies use cases to create principles?

\section{The Case Method - Epistemological Foundations}

Much research in business disciplines is based on a positivist epistemology (Wai Fong, 1986:606), namely, the idea that reality is objective and knowable and can be discovered through the scientific examination of empirical evidence. Pinpointing the evidence to be examined, however, is a step in this process which perhaps receives less attention than it merits. As Wynn and Williams aptly described it, "In order to theorize about the causes behind a series of events, it is first necessary to decompose the relevant structure into its constituent parts such as actors, rules, relationships, etc." (2012:798). Case studies are generally intended to examine a single or a limited set of circumstances in detail, to understand the "peculiarities and complexities" of an event or a situation (Stake, 1995: xi). By examining structure and context, the research endeavors to uncover those factors which contributed to or caused the effects being studied (Wynn and Williams, 2012:798). In this light, case studies have a useful purpose as one of the building blocks of a research plan.

Based in part on Wai Fong's (1986) critique of positivism as the basis of business research, Wynn and Williams (2012) convincingly argue that critical realism is a viable epistemological foundation on which to base investigations of structures and behaviors. As explained by Bhaskar and Danermark, critical realism has several advantages over alternative epistemological approaches (2006:280). They argue that reality is an objective thing, but that it is understood and interpreted by people, and that research based on this premise can be more inclusive than research that assumes either a positivist or a relativist epistemology. Further, and unlike research which tests binary hypotheses, it is not reductionist. Most pointedly, the authors argue that "critical realism indicates more clearly than the other positions the appropriate direction and context of explanatory research from the manifest phenomena to the mechanisms that produce them, in their complex co-determination" (2006:280). Precisely because it recognizes that social actors interpret reality, it does not assume that either objective reality or that actors' perceptions of it should be researched as isolated events.

Case studies provide the research framework within which an observation and analysis of behavior in relation to both structure and mechanisms can be conducted. Both aspects lend themselves to critical analysis: What was the environment and what were the events that are to be examined? How were they perceived and interpreted by the actors? What were the resultant behaviors and outcomes of this confluence of objective reality and purposeful action?

\section{The Research Framework - Approaches in Management and Law}

Over the last two decades, significant contributions to case study design in management research have been made separately by Stake and Yin. Stake provides an outline for case study design that involves six steps (2005:459460):

a) Bounding the case, conceptualizing the object of the study

b) Selecting phenomena, themes or issues (i.e., the research questions to emphasize)

c) Seeking patterns of data to develop the issues

d) Triangulating key observations and bases for interpretation

e) Selecting alternative interpretations to pursue

f) Developing assertions or generalizations about the case

Yin's guidance on case study research design was less specific than that of Stake in terms of how to collect and arrange data for analysis, but it added two steps to the process of analyzing the data (2009:34-35), instructing the researcher to determine: 
a) What data are to be collected

b) The research propositions

c) The units of analysis

d) The logic linking the data to the propositions

e) The criteria for interpreting the findings

While a more classical approach to research design would call for developing research propositions before determining what data are to be collected and the units of analysis appropriate to the question, Yin's systematic approach is a generalist one. The steps outlined could be applied to qualitative as well as quantitative research.

In legal studies, a case analysis results in a comprehensive brief - a summary of its key elements. The typical brief template consists of ten elements (Statsky and Wernet, 1995:136-137):

a) The parties (Who are the principle actors in the case?)

b) Their objectives

c) The cause of action (the basis on which a law suit was filed, e.g., Brown breached her duty to pay rent under the lease contract)

d) The defense (e.g., the lease was made in violation of a housing regulation and is unenforceable)

e) The case history (prior proceedings)

f) The nature of the present proceeding

g) Key facts

h) The "issue" to be decided

i) The holding of the court

j) The reasoning of the court

The legal case analysis embraces critical realism in that it examines events and mechanisms, and assumes that in a conflict plaintiffs and defendants typically have divergent motives and perceptions of reality. In determining what data is to be collected, "key facts" are limited to those that are essential to the decision to be made; collateral data as well as the introduction of non-essential parties is not permitted (Statsky and Wernet, 1995:82 et seq.). The issue to be decided and the holding are akin to the research proposition in management research. The sequence of steps differs between the two systems because in law, as opposed to management research, the conflict rather than a theory to be tested drives the process.

\section{The Uses of Management Case Studies}

To understand how case studies are currently being used in management literature, a review of all of the case studies available through the Business Source Complete database between 2006 and 2012 was undertaken. In order to be able to interpret these studies, several additional constraints were placed on the search: The papers were limited to those (1) published as articles, (2) in academic journals, (3) in English, (4) with a full .pdf available. The search produced 223 results. After duplicates were eliminated, the results were scanned for relevance. As this study is limited to management topics, those cases that analyzed medical, healthcare or other scientific issues, urban planning and sociological studies, and political events were eliminated, leaving 139 usable results.

The most frequent use of the case study was for educational purposes; this category of cases included those that discussed the merits of using cases as a pedagogical tool as well as those that presented a case along with recommendations for its interpretation in a classroom setting. The next most frequent use was in interpreting either strategies or relationships - the how and why of certain decisions and the impact these decisions had on organizational design, human resource planning or resource use. Third was the analysis of external influences and their impact on the firm; these included such topics as trends in market forces, changes in available technology, and crisis management situations. Fourth was for the development of "best practices" in a variety of contexts from marketing to information technology, and fifth were those cases that considered a management theory and used a case study to demonstrate its application in a business situation. 


\begin{tabular}{|l|l|}
\hline Case Purpose & Frequency of Use \\
\hline Pedagogical or instructional & $34 \%$ \\
\hline Interpreting strategies or relationships & $18 \%$ \\
\hline Development of "best practices" & $17 \%$ \\
\hline Analysis of external influences on the firm & $14 \%$ \\
\hline Demonstrations of management theory & $12 \%$ \\
\hline All other & $5 \%$ \\
\hline
\end{tabular}

Source: Business Source Complete - Jan '06 to Oct '12

There were four papers that either proposed that theory could be constructed based on case study evidence or that actually developed a theory. One was a review of cases in construction and engineering management (Taylor, Dossick, and Garvin, 2011). The second was a proposal for a model of the development of spin-off ventures and was based on an analysis of 17 case studies (De Cleyn and Braet, 2010). The third was an issue-based case study defining the meaning and design of farmers' markets as public spaces and reviewed the 60 most popular farmers' markets in the U.S. to develop four design principles--permanency of design, flexibility, wholeness, and social life that characterize them (Francis, and Griffith, 2011). The fourth concerned the development of a theory describing the ways in which product concepts evolve during development and entailed a review of six cases and interviews with 51 participants in those cases (Seidel, 2007).

\section{DISCUSSION}

There are circumstances where replicating an event may be neither possible nor desirable. Situations involving crises, events where there was a loss of life or property (see: Bridgman, 2010), or other unlikely or complex circumstances may provide the basis for the development of theory. The learning opportunity that these situations provide should not be forgone simply because the situation is not one that can or should be replicated.

The case study approaches used in management and in law differ in two critical respects: (1) the degree to which data that is irrelevant or marginally relevant can be included in the case discussion, and (2) whether a policy can be developed on the basis of what is being considered. The purpose of the case discussion in law is to identify the actors, events, circumstances, and relationships necessary to a decision, and on the basis of this combination of factors to create a rule. It is a replicable decision in that once a precedent is set in a given jurisdiction; the rule may be expected to be followed given the same or a similar set of factors.

Yin argues that a case that follows the five point design outlined above is sufficient to construct a preliminary theory related to the topic being considered (2009:35), but cautions that it should "by no means be considered with the formality of grand theory in social science" (2009:36). He does, however, state that a case study can be used to test a theory or to compare a theory to a rival theory on the basis of an "analytic generalization" (2009:39), which can take the form of pattern matching (2009:136), explanation building (2009:141), time series analysis (2009:144), logic models (2009:149), or cross-case synthesis (2009: 156). Each of these forms, however, departs from the single-case-to-theory model used in legal studies.

In the cases reviewed for this study, one was an assessment of cases used to develop principles in construction and engineering, a discipline that more closely follows a physical science than a social science model. The other three articles entailed surveys of small sample sets of cases and proposed theories or principles based on commonalities within the cases studied. One of these cases provided a typology based an interpretation of events, while the other two proposed models that could be tested with further research. There were no cases found in which a theory was proposed based on a single case study.

The case approach used in legal studies more closely resembles the physical science than the social science model. While the factors being studied are not in a controlled environment, they are limited and examined within the context of their environment. Rules are derived based on evidence which is, ideally, complete but limited to that necessary to decide the case. For a management case study to be used as the basis for proposing a theory, the evidence would similarly have to satisfy the requirements of sufficiency and completeness, and be presented without extraneous material. The social science model of management makes this combination of events unlikely, although not impossible. 


\section{CONCLUSION}

Given a well-constructed case, generalizable rules can be derived from a single case study and proposed for testing in subsequent studies. There are circumstances, e.g., crises, where injury to people or property has occurred, where the ability to replicate an event would be undesirable. Similarly, there are circumstances that are either so unique or complex that replication is not possible. Neither of these factors should prevent what has been studied from becoming a learning opportunity, nor should it prevent a researcher from proposing generalizations based on his or her findings.

Care should be taken, however, to ensure that the evidence on which a proposed theory may be based completely defines its context. The challenge is clear: Case studies are often used to describe complex situations, and the richness of the learning opportunity they provide includes sifting relevant from collateral data, assessing the perspectives of the actors and understanding the mechanisms by which events have occurred. Of course, the more intricate the case, the more tempting it is to investigate the impact of each of the nuances which help to shape the outcome. Nonetheless, case studies remain rich opportunities for proposing and testing management theory.

\section{AUTHOR INFORMATION}

Robert Klonoski, JD, D.Mgt., is an Assistant Professor of Business Administration at Mary Baldwin College in Virginia, USA. His research interests include educational technologies and work motivation. He has also taught at the University of the District of Columbia, the University of Virginia and has worked in the financial services industry. Professor Klonoski holds a B.S. in Finance from Fairfield University, an M.B.A. from the University of Connecticut, a J.D. from Brooklyn Law School, and a Doctorate in Management at the University of Maryland. E-mail: rklonosk@mbc.edu

\section{REFERENCES}

1. Baldwin, S. E. (1900). Teaching law by cases. Harvard Law Review, 14(4), 258-261.

2. Bhaskar, R., \& Danermark, B. (2006). Metatheory, interdisciplinary and disability research: A critical realist perspective. Scandinavian Journal of Disability Research, 8(4), 278-297. doi:10.1080/15017410600914329

3. Bridgman, T. (2010). Beyond the manager's moral dilemma: Rethinking the 'ideal-type' business ethics case. Journal of Business Ethics, 94(311-322). doi:10.1007/s10551-011-0759-3

4. Bygstad, B. (2010). Generative mechanisms for innovation in information infrastructures. Information and Organization (20), 156-168.

5. De Cleyn, S. H., \& Braet, J. (2010). The evolution of spin-off ventures: An integrated model. International Journal of Innovation \& Technology Management, 7(1), 53-70.

6. Francis, M., \& Griffith, L. (2011). The meaning and design of farmers' markets as public space: An issuebased case study. Landscape Journal, 30(2), 261-279.

7. Harvard Business School (n.d.) Field: Global immersion. Retrieved 11/1/2012 from: http://www.hbs.edu/mba/ academic- experience/FIELD/Pages/default.aspx

8. Kimball, B. A. (2009). The Inception of Modern Professional Education: C. C. Langdell, 1826-1906 (Chapel Hill: University of North Carolina Press, 2009).

9. Kolb, D. (1984). Experiential Learning: experience as the source of learning and development. Englewood Cliffs, NJ: Prentice Hall.

10. Seidel, V. P. (2007). Concept shifting and the radical product development process. Journal of Product Innovation Management, 24(6), 522-533. doi:10.1111/j.1540-5885.2007.00269.x

11. Smith, I. H., \& Woodworth, W. P. (2012). Developing social entrepreneurs and social innovators: A social identity and self-efficacy approach. Academy Of Management Learning \& Education, 11(3), 390-407.

12. Stake, R. (1995). The art of case study research. Thousand Oaks, CA: Sage.

13. Stake, R. (2005). Qualitative case studies. In N. Denzin \& Y. Lincoln (Eds.), The Sage handbook of qualitative research $\left(3^{\text {rd }}\right.$ ed., pp. 443-466). Thousand Oaks, CA: Sage.

14. Statsky, W. \& Wernet, Jr., R. J. (1995). Case analysis and fundamentals of legal writing, $4^{\text {th }}$ ed., St. Paul, MN: West Publishing. 
15. Taylor, J. E., Dossick, C., \& Garvin, M. (2011). Meeting the burden of proof with case-study research. Journal of Construction Engineering \& Management, 137(4), 303-311. doi:10.1061/(ASCE)CO.19437862.0000283

16. Wai Fong, C. (1986). Radical developments in accounting thought. Accounting Review, 61(4), 601.

17. Wynn, J., \& Williams, C. K. (2012). Principles for conducting critical realist case study research in information systems. MIS Quarterly, 36(3), 787-810.

18. Yin, R. (2009). Case study research: Design and methods. Thousand Oaks, CA: Sage Publications

19. Zivkovic, J. (2012). Strengths and weaknesses of business research methodologies: Two disparate case studies. Business Studies Journal, 4(2), 91-99. 